\title{
Cellulase vs rumen fluid for in vitro digestibility of mixed diets
}

ROY LEE DICKERSON, JR., BILL E DAHL, AND GRETCHEN SCOTT

\begin{abstract}
Nutritional studies frequently require an estimate of animal diet digestibility, but current in vitro techniques require costly fistulated animals, and variation in rumen fluid activity often results in poor precision. Hoping to find a more precise, yet cheaper, alternative, we examined estimates of organic matter digestibility of cattle diets based on a cellulase technique and compared them to those based on in vitro digestions. Diets were determined using microhistological analysis of native range forages, weeping lovegrass, and wheat pasture from May 1985 through May 1986. The 2 techniques offered estimates that were highly correlated $(r=0.91$ to 0.94$)$ when diets consisted of cool-season grasses and forbs. Digestibility estimates of diets by the 2 techniques for predominantly warm-season species on native range were less well correlated $(r=0.81$ to 0.86$)$. Agreement between the 2 techniques was relatively poor for mixed species diets from weeping lovegrass pastures $(r=0.48)$. We conclude that in vitro digestion using cellulase offers a promising approach for assessing diet quality, particularly with diets dominated by graminoids.
\end{abstract}

Key Words: IVDOM, cellulase, in vitro digestibility, mixed diets, cellulase vs. rumen fluid, microhistological analyses

Authors are graduate research assistant, professor, and laboratory supervisor, Range and Wildlife Management Department, Texas Tech Univ., Lubbock 79409. Dr. Roy Lee Dickerson, Jr., is currently technical manager for the Beef Cattle Group. Purina Mills, Inc., Box 66812, St. Louis, Missouri 63166. Contribution from the College of Agricultural Sciences, Texas Tech University published as paper No. T-9-478.

Manuscript accepted 11 February 1988.
Digestion of forages by in vitro techniques (Tilley and Terry 1963) has proved to be one of the most accurate laboratory methods for predicting apparent in vivo dry matter digestibility (DMD) of temperate and tropical pasture plants (McLeod and Minson 1969, 1976). Van Soest et al. (1966) proposed a modification to the Tilley and Terry in vitro rumen procedure using neutraldetergent solution as a substitute for the second stage acid pepsin treatment and arrived at digestibilities numerically equivalent to true digestibility in vivo. Both techniques, however, depend on a constant source of fresh rumen fluid from fistulated animals (McLeod and Minson 1978), which require expensive care (Goto and Minson 1977). Other problems include variation in the activity of rumen fluid, even when animals were fed similar forages. This variation causes poor precision (Tilley and Terry 1963).

To overcome these problems, Donefer et al. (1963) suggested that cellulase might be used as an alternative to rumen microorganisms. This approach allows researchers to obtain estimates of DMD inexpensively when fistulated animals are unavailable (Bughrara et al., 1985), and may enhance precision (Clark and Beard 1977). Many studies using cellulase to estimate forage digestibility have been initiated (McLeod and Minson 1978, McLeod and Minson 1982, Bughrara and Sleper 1986). All of these studies were conducted with a single species of forage. The objective of our research was to compare the in vitro rumen fluid-neutral detergent digestible organic matter (RNDOM) (Van Soest et al. 1966) of diet samples comprised of grasses and forbs with values derived with a 
cellulase-neutral detergent organic matter (CNDOM) technique.

\section{Methods}

\section{Diet Sample Determination}

Cattle diets were sampled from May 1985 through May 1986 on the Post-Montgomery ranch located $11 \mathrm{~km}$ northeast of Post, Texas, and on the Mesquite Grove ranch located $3 \mathrm{~km}$ east of Clairmont, Texas. The Post study site included native, continuously grazed pastures (NC) and native, rotationally grazed pastures (NR) on sand shinnery oak (Quercus havardii) range. Dominant grasses and forbs were hooded windmillgrass (Chloris cuculata), sand paspalum (Paspalum setaceum), sand dropseed (Sporobolus cryptandrus), sandbur (Cenchrus incertus), western ragweed (Ambrosia psilostachya), wild buckwheat (Eriogonum annum), and evening primrose (Oenothera rhombipetala).

The Mesquite Grove study site included 2 rotationally grazed cells located in the east and south portions of the ranch. Commonly occurring grasses and forbs on the east cell (EC) included cool-and early maturing warm-season grasses and forbs: canary grass ( $P$ halaris caroliniana) white tridens (Tridens albescens), rescue grass (Bromus unioloides), plains bristlegrass (Setaria leucopila), sleepdaisy (Xanthisma texanum), and Englemann daisy (Engelmannia pinnatifida). Major grasses and forbs on the south cell (SC) included little bluestem (Schizachyrium scoparium), sand dropseed, sideoats grama (Bouteloua curtipendula), sandbur, sleep daisy, and wild buckwheat.

Samples for diet analysis were also collected from animals grazing weeping lovegrass (WL) (Eragrostis curvula) pastures on the Post-Montgomery Estate ranch and wheat pastures (WP) of nearby ranches. The lovegrass pastures included the grasses and forbs common to nearby native pastures in addition to the lovegrass. In all, 159 cattle diets were estimated from composite microhistological fecal samples (Holechek and Valdez 1985, Holechek et al. 1985). Samples were collected several times each week during the growing season (April through September), and every 2 weeks during the dormant period (October through March). Subsamples of fresh feces, taken from 2 to 5 defecating animals per pasture, were mixed in a blender, with ethanol (95\%) added to remove pigmentation. After filtering, the undigested plant residue was placed on a slide and the species identified under a microscope using 100 power magnification. The objective was to identify in the field the proportion of plants in the diet and then to harvest, by weight, those same species on the same day. Composite diet samples were placed in sealed plastic bags, weighed wet, oven dried $\left(59^{\circ} \mathrm{C}\right)$, ground to pass a $1-\mathrm{mm}$ screen, and analyzed for RNDOM, CNDOM, and crude protein (AOAC 1975).

Our lab analyses indicate that cellulase digestion of forage samples followed by neutral detergent treatment gives reasonably close values to traditional IVOMD values. Thus, we replaced the rumen fluid phase with cellulase and left all other procedures the same for this study.

In Vitro Rumen Fluid-Neutral Detergent Organic Matter (RNDOM)

RNDOM was determined on $0.5 \mathrm{gm}$ of each sample. Six, grain sorghum forage standards of known digestibility and 2 blanks were included in each run to correct in vitro values to in vivo digestibility. Differences in digestion coefficients of standards among runs averaged 3.7 percentage points. Approximately half the samples from all test pastures were included in each run. Duplicate samples were included in separate runs. Duplicates varying as much as $10 \%$ were repeated. Ten $\mathrm{ml}$ of filtered rumen fluid, obtained from a steer on an alfalfa diet, and $20 \mathrm{ml}$ of McDougal's solution were added to each 0.5 -gm sample. To simulate anaerobic rumen conditions, the tubes were flushed with $\mathrm{CO}_{2}$ and then stoppered with a bunsen one-way valve. Samples were incubated for $48 \mathrm{hr}$ at $39^{\circ} \mathrm{C}$ and agitated every $12 \mathrm{hr}$ to insure adequate mixing of rumen fluid and sample.

Following the 48-hr digestion, each sample was refluxed with $100 \mathrm{ml}$ of neutral detergent for 1 hour (Van Soest et al. 1966). Samples were filtered and rinsed with acetone to remove all neutral detergent, dried at $100^{\circ} \mathrm{C}$, and ashed.

\section{In Vitro Cellulase-Neutral Detergent Digestible Organic Matter (CNDOM)}

CNDOM was determined on $0.5 \mathrm{gm}$ of each diet sample. Six standards included per run were the same as those used for RNDOM. Variation in digestion coefficients among the standards ranged from 1.7 to 2.5 percentage points. Onozuka $3 \mathrm{~s}$ cellulase with buffer solution was used because of its broad spectrum cellulase activity (McLeod and Minson 1980). The cellulase-buffer solution (per liter) was $4.102 \mathrm{~g}$ of $0.5 \mathrm{~m}$ sodium acetate $\left(\mathrm{NaC}_{2} \mathrm{H}_{3} \mathrm{O}_{2}\right.$ ), $2.86 \mathrm{ml}$ of $0.05 \mathrm{M}$ glacial acetic acid $\left(\mathrm{C}_{2} \mathrm{H}_{4} \mathrm{O}_{2}\right), 0.1 \mathrm{gm}$ chloromphenical, and $12.5 \mathrm{gm}$ of Onozuka $3 \mathrm{~s}$. Fifty $\mathrm{ml}$ of the cellulasebuffer solution was added to each $0.5 \mathrm{gm}$ sample in a $100 \mathrm{ml}$ polyethylene cent rifuge tube, stoppered, and incubated for $48 \mathrm{hr}$ at $39^{\circ} \mathrm{C}$. Samples were agitated at $12-\mathrm{hr}$ intervals to insure adequate mixing. Following the 48-hr digestion, samples were treated with neutral detergent, refluxed, filtered, dried and ashed as in the RNDOM technique.

Estimates of diet digestible organic matter obtained from the RNDOM were compared to the CNDOM using regression analysis. Residual standard deviations (RSD) were calculated to indicate the deviation in digestibility units.

\section{Results and Discussion}

CNDOM was significantly correlated $(P<0.05)$ with RNDOM for each collection date at each of the study pastures (Table 1). Correlations were similar for the diets evaluated from native range (NC, $r=0.83 ; \mathrm{NR}, r=0.81$; SC, $r=0.86$; and EC, $r=0.91$ ). These values were lower than those derived for the individual grass

Table 1. Pasture averages for dietary forbs, crude protein (CP), and in vitro digestibility. Also, correlation coefincients (r) for rumen fluid-neutral detergent digestible organic matter (RNDOM) vs cellulase-neutral detergent digeatible organic matter (CNDOM) from cattle diet samples for each pasture location is included.

\begin{tabular}{|c|c|c|c|c|c|c|c|}
\hline Location ${ }^{1}$ & Observations & Forbs (\%) & $\mathrm{CP}(\%)$ & RNDOM (\%) & CNDOM (\%) & $r * *$ & Regression \\
\hline $\begin{array}{l}\text { NC } \\
\text { NR } \\
\text { WL } \\
\text { EC } \\
\text { SC } \\
\text { WP } \\
\text { Native }\end{array}$ & $\begin{array}{r}49 \\
32 \\
27 \\
17 \\
26 \\
6 \\
124\end{array}$ & $\begin{array}{r}28 \\
32 \\
21 \\
25 \\
35 \\
0 \\
30\end{array}$ & $\begin{array}{r}7.7 \\
8.1 \\
8.4 \\
9.1 \\
6.3 \\
15.8 \\
7.7\end{array}$ & $\begin{array}{l}44.6 \\
47.0 \\
44.2 \\
54.2 \\
42.1 \\
75.3 \\
46.0\end{array}$ & $\begin{array}{l}41.8 \\
45.5 \\
43.4 \\
49.2 \\
39.6 \\
77.0 \\
43.3\end{array}$ & $\begin{array}{l}0.83 \\
0.81 \\
0.48 \\
0.91 \\
0.86 \\
0.98 \\
0.85\end{array}$ & $\begin{array}{l}Y=10.4+.818 x \pm 5.2 \\
Y=10.1+.810 x \pm 4.2 \\
Y=19.9+.560 x \pm 5.3 \\
Y=20.1+.687 x \pm 2.4 \\
Y=15.5+.672 x \pm 3.0 \\
Y=36.3+.506 x \pm 1.0 \\
Y=10.3+.823 x \pm 4.4\end{array}$ \\
\hline
\end{tabular}

${ }^{1} \mathrm{NC}=$ Post native continuous pastures

NR = Post native rotation pastures

$\mathrm{WL}=$ Post lovegrass pastures

$\mathrm{EC}=$ Mesquite Grove east rotation pastures

$\mathrm{SC}=$ Mesquite Grove south rotation pastures
Native = all NC, NR, EC and SC pastures

WP $=$ wheat and oat pastures

${ }^{2}$ RSD = Residual standard deviation in digestibility units

**All correlations significant $P<.01$ 
species ( $r=0.99$ ) analyzed by Bughrara et al. (1985). Diet samples from the NC, NR, and SC pastures consisted of warm-season grasses and forbs whereas the EC pasture diets included coolseason grasses. Warm-season grasses may have higher cell wall content than cool-season grasses (Barton et al. 1976, Windham et al. 1983), which could have contributed to the lower digestibilities observed for the NC, NR, and SC pastures. High IVOMD values were obtained for diets from the EC pastures, where cattle diets had higher proportions of cool-season grasses. When the diets consisted of only cool-season wheat or oats, the relationship between RNDOM and CVDOM was high $(r=0.98)$. Correlation between RNDOM and CNDOM for mixed forage in the weeping lovegrass pastures was low $(r=0.48)$.

Bughrara et al. (1985) found a wide range in correlation coefficients for individually analyzed forbs using the cellulase procedure as a means of predicting in vitro digestibility $(r=0.24$ to 0.99$)$. Forb content in our composite grass and forb diet samples ranged from $0-60 \%$. However, when percent forbs in the diets was regressed against deviation of CNDOM and IVDOM, no correlation existed $(r=0.11)$, indicating that the forb diet component did not influence the results. Similarly, when digestibility was regressed against deviation of CNDOM from RNDOM, the regression was not significant $(P>0.05, r=0.079)$, which indicates that little difference existed between the techniques for predicting digestibilities throughout the 20-80\% range of values for our study. However, a $t$ test for paired differences did indicate that the CNDOM technique gave lower $(P<0.01)$ digestibility values (Table 1$)$.

Range researchers seldom have the luxury of dealing with pastures offering a single forage to grazing animals. We attempted to determine if digestibility of mixed diets could be estimated as precisely with a cellulase technique as with a rumen fluid technique. Although lack of a high correlation between the 2 techniques for cattle diets from the lovegrass pastures was disappointing, we could not tell which of the 2 methods was more accurate. As pointed out by Minson (1981), the main factor controlling the magnitude of the residual standard deviation (a measure of the scatter about the regression line) is the existence of different regressions for different forages. This is true for techniques based on cellulase as well as rumen fluid. Those of us forced to deal with complex mixes of native forages may have to be content with a "reasonable estimate" of digestibility. The fact that the cellulaseneutral detergent technique appeared at least as precise as the rumen fluid-neutral detergent technique encourages its further evaluation and use. Also, variation in digestion coefficients among the CNDOM standards was more precise than for RNDOM runs.

\section{Conclusions}

Use of the cellulase as a replacement for rumen fluid has been suggested (Donefer et al, 1963). Comparisons of the 2 techniques based upon individual grass and forb species resulted in high correlations ( $r=0.94$ to 0.96 ). Considerable savings in time, cost and possibly variation in the activity of the rumen fluid between runs of digestibility samples would be possible if cellulase could be used to evaluate diet samples comprised of mixtures of grasses and forbs.

Our highest correlations ( $r=0.99$ ) were from a single species wheat pasture, followed by a dietary mixture which contained cool-season and early maturing warm-season grasses $(r=0.91)$. Intermediate correlations were from native pastures containing predominantly later maturing warm-season forage $(r=0.81-0.86)$.
The lowest correlation was on mixed forage from weeping lovegrass pastures $(0.48)$. The fact that different forages have different digestibility regressions through the season (Minson 1981) may preclude extremely high correlations among techniques that estimate digestibility of complex mixed forage diets. Although, this study did not compare in vitro to in vivo digestibilities, it did indicate that cellulase can estimate digestibility just as precisely as rumen fluid techniques. Fears that cellulase could not digest complex mixtures as well as rumen fluid based techniques seem unfounded. However, our digestibility coefficients were 2 to 3 percentage points lower with the cellulase technique throughout the range of digestibilities normally encountered, at least those values below $70 \%$.

\section{Literature Cited}

AOAC. 1975. Official methods of analysis (11th Ed.). Assoc. Official Analyt. Chem., Washington, D.C.

Barton, F.E. II, H.A. Amos, D. Burdick, and R.L. Wilson. 1976. Relationship of chemical analysis to in vitro digestibility for selected tropical and temperate grasses. J. Anim. Sci. 43:504-512.

Bughrara, S.S., and D.A. Sleper. 1986. Digestion of several temperate forage species by a prepared cellulase. Agron. J. 78:94-98.

Bughrara, S.S., D.A. Sleper, O.H. Calvert, and G.C. Marten. 1985. Predicting in vitro digestibility with a simple potent cellulase procedure. In: p. 828-830. XVth Int. Grassl. Conf. Proc. Publisher Iroha Insatsu Koger Co., Nagoya, Japan.

Clark, J., and J. Beard. 1977. Predicting of the digestibility of ruminant feeds from their solubility in enzyme solutions. Anim. Feed Sci. and Technol. 2:153-159.

Donefer, E., P.J. Niemann, E.W. Crampton, and L.E. Lloyd. 1963. Dry matter disappearance by enzyme and aqueous solutions to predict the nutritive value of forages. J. Dairy Sci. 46:965-970.

Goto, I., and D.J. Minson. 1977. Prediction of the dry matter digestibility of tropical grasses using pepsin-cellulase assay. Anim. Feed Sci. Technol. 2:247-253.

Holechek, J.L., and R. Valdez. 1985. Magnification and shrub stemmy material influences on fecal analysis accuracy. J. Range Manage. 38:350-352.

Holecheck, J.L., M. Vavra, D. Manzananes, M. Sanchez, and J. Boshe. 1985. A comparison of esophageal fistula and fecal material to determine cattle diet botanical composition. Proc. Western Sect. Amer. Soc. Anim. Sci. 36:286-289.

McLeod, M.N., and J.D. Minson. 1978. The accuracy of the pepsincellulase technique for estimating the dry matter digestibility in vivo of grasses and legumes. Anim. Feed. Sci. Technol. 3:277-287.

MeLeod, M.N., and J.D. Minson. 1982. Accuracy of predicting digestibility by the cellulase technique; the effect of pretreatment of forage samples with neutral detergent or acid pepsin. Anim. Feed Sci. Technol. 7:83-92.

Minson, D.J. 1981. An Australian view of laboratory techniques for forage evaluation. p. 57-73. In: Wheeler, J.L., and R.D. Mochrie (eds). Forage evaluation: concepts and techniques. Commonwealth Scientific and Industrial Research Organization (Australia). CSIRO (Australia) and American Forage and Grassland Council (USA).

Tilley, J.M.A., and R.A. Terry. 1963. A 2 stage technique for in vitro digestion of forage crops. J. Brit. Grassl. Soc. 18:104-111.

Van Soest, P.J., R.H. Wine, and L.A. Moore. 1966. Estimation of the true digestibility of forages by the in vitro digestion of cell walls. 10th Int. Grassl. Conf.

Windham, W.R., F.E. Barton, II, and D.S. Himmelsbach. 1983. Highpressure liquid chromatographic analysis of component sugars in neutral detergent fiber for representative warm and cool-weason grasses. J. Agr. Food Chem. 31:471-475. 